\title{
Changes in Haircut Shapes by Mixing Medium-Graduation Haircut and One Length Haircut according to the Division of Head and Slice Lines during Hair Cutting I
}

Seon-Mi Jang, Won-Ji Jung*

Department of Beauty Science, Kwangju Women's University, Kwangju, Korea

\author{
Corresponding author: Won-Ji Jung, \\ Department of Beauty Science, Kwangju \\ Women's University, 69 Kwangju Yeodae- \\ gil, Gwangsan-gu, Gwangju 62396, Korea \\ Tel.: +82629503798 \\ Fax: +82 629503797 \\ Email: jwj65@hanmail.net
}

Received March 26, 2021

Revised April 19, 2021

Accepted April 26, 2021

Published June 30, 2021

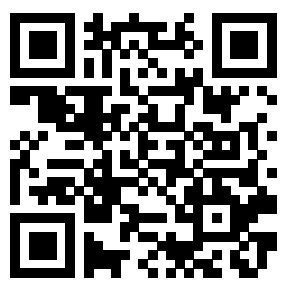

\begin{abstract}
Purpose: Here we provide basic data for haircut style education by applying a combination of two basic hair cut styles, medium graduation cut and one-length cut based on the division of the scalp, and demonstrating change of shape and length of the cut depending on the location of the slice lines. Method: After dividing the hair into the front side point-golden point+2 $(\mathrm{F}-\mathrm{G}+2)$, side point-golden back medium point+1 (S-GBMP+1), and ear point-back point $(\mathrm{E}-\mathrm{B})$, one-length cut and medium graduation cut were applied to the upper and the lower part respectively. Finally, the hair cut was completed using slice lines of $A$ line, parallel line and $V$ line. Result: After dividing the hair, the one-length cut was applied to the upper part and the medium graduation cut to the lower part. As a result, there were changes in the shape of the haircut and the length of the hair depending on the location of division, and the shape lines were found to be affected by slice lines of the medium graduation cut. Conclusion: We demonstrate that when basic haircuts are combined, the shape of the haircut varies depending on the characteristics of cuts applied to each divided location, and a unique and creative haircut could be designed when diverse slice lines are applied.
\end{abstract}

Keywords: Haircut, Slice line, Medium-graduation cut, One-length cut, Combination cut

\section{Introduction}

헤어 미용은 현장성을 중시하는 대표적인 직업 군이며 헤어 미용 에 관한 교육은 대다수가 산업현장에서 직무수행을 위해 이루어진다 (Lee \& Park, 2016). 헤어 커트는 헤어 미용의 영역 중에서도 구조적 인 틀을 만드는 기초작업으로 그 중요성과 헤어스타일 연출에 비중이 크다(Jung \& Youn, 2008). 또한 퍼머넌트 웨이브나 염색보다 환경 친 화적이며 모발의 손상을 초래하지 않는다는 장점이 있다(Kwon et al., 2010).

헤어 커트의 기초로 분류(Kim et al., 2018b) 되는 미디엄 그래주에 이션 커트와 원랭스 커트는 미용 현장에서 많이 시술되는 커트 형태 로서 시술각도에 따라 구분된다(Kim et al., 2018a). 두상시술각을 사 용하는 미디엄 그래주에이션 커트는 시술각에 따라 로우(low), 미디엄 (medium), 하이 그래주에이션(high graduation)으로 분류하며 다양한 시술각도를 혼합 적용하여 헤어 커트를 디자인 할 수 있다(Lee, 2000).
원랭스 커트는 자연시술각도를 적용하기 때문에 모든 모발이 같은 선 상에 위치하게 되며 이로 인한 형태선의 단조로움은 슬라이스 라인으 로 변화를 줄 수 있다(Lee \& Jin, 2010), 슬라이스 라인은 얇게 나눈 다는 의미로 헤어 커트를 시술하기 쉽게 분할하는 선 중 제일 작은 단 위이다(Kim \& Lee, 2017). 슬라이스 라인은 A 라인(concave line), 평 행라인(parallel line), $\mathrm{V}$ 라인(convex line)으로 나눌 수 있으며 슬라 이스 라인의 기울기에 따라서 다양한 헤어 디자인이 가능하다(Jung, 2011). 뒤쪽에서 얼굴 쪽으로 갈수록 커트 선의 길이가 길어지는 A 라 인(concave line)은 전경사 또는 전대각 이라고 하며, 뒤쪽에서 얼굴 쪽 후경사 또는 후대각 이라고 한다(Kang, 2003).

헤어 커트는 슬라이스 라인의 혼합, 기초 헤어 커트의 혼합, 시술각 도의 혼합 등 다양한 요소들의 혼합을 통해 창의적인 커트 디자인이 가능하다(Kim, 2016). 헤어 커트를 이루는 요소들은 각각의 이미지와 으로 이동 할수록 커트 선의 길이가 짧아지는 $\mathrm{V}$ 라인(convex line)은 
특징을 가지고 있다(Jung \& Kim, 2017). 이러한 요소들의 특징을 혼합 하면 고객의 요구에 부합하고 디자이너의 감성을 충족 시킬 수 있는 커 트 스타일을 창출 할 수 있다.

기초 헤어 커트의 혼합에 관한 선행 연구를 찾아보면 Jung \& Kim (2017)은 이사도라 커트와 그래주에이션 커트의 혼합형 스타일의 형태 변화를 실증한 후 발표하였으며 Jang \& Jung (2020b)은 원랭스 커트와 세임 레이어 커트를 두상의 분할과 슬라이스 라인에 따라 변화되는 커 트형태와 길이 변화를 실증하여 헤어 커트의 기초자료를 제공하였다. 원랭스 커트와 미디엄 그래주에이션 커트의 혼합에 관한 연구결과도 보 고되었는데 두상의 분할과 슬라이스 라인에 따라 볼륨과 입체감이 달라 지는 것을 실증한 연구도 보고 되었다(Jang \& Jung, 2020a).

슬라이스 라인의 혼합에 관한 선행 연구를 살펴보면 Jang \& Jung (2019b)은 전경사와 후경사 슬라이스 라인을 미디엄 그래주에이션 커 트에 혼합한 후 변화되는 형태와 길이를 실증하여 커트 디자인의 기초 자료를 제공하였으며 다양한 전경사 슬라이스 라인을 헤어 커트에 적용 한 후 전경사의 기울기 만으로도 두형과 얼굴형을 보완할 수 있다는 것 을 증명한 연구도 있다(Jang \& Jung, 2019a). 또한 Kim (2016)은 블록 의 양과 모발의 길이, 섹션라인과 같은 요소들의 조합에 따라 다양한 헤 어 스타일이 창출 될 수 있다는 것을 연구를 통해 증명하였다.

헤어 커트를 배우는 학생들은 NCS를 기반으로 하는 커트 교육 프로 그램을 시작으로 헤어 커트에 입문한다. 그리고 미용현장에서 실무에 종사하다 커트 교육의 필요성을 느껴 다시 재교육 기관을 찾는 경우가 비일비재하다. Kwon et al., (2010)은 커트 교육 시 두상의 기준점과 모 발길이의 수치화의 필요성에 관한 기초자료를 조사하여 발표하였는데 응답자의 대부분이 그 동안 받았던 커트교육에 불만족하고 있으며 수치 화된 커트교육의 필요성을 느끼고 있는 것으로 조사되었다. 이렇듯 헤 어 커트는 한번의 배움으로 끝나지 않으며 재교육의 필요성이 절실한 실정이다. 이에 많은 연구자들은 감각에 의존하는 커트시술의 빈도를 줄이고 헤어 커트를 체계화, 수치화 시키는 연구에 노력을 기하고 있다 (Seo \& Song, 2019).

이에 본 연구는 미디엄 그래주에이션 커트와 원랭스 커트를 두상의 영역분할에 혼합한 후 슬라이스 라인에 따라 변화되는 커트의 형태변화 와 길이 변화를 실증하여 헤어 커트 교육의 기초자료로 제공하고자 한 다.

\section{Methods}

\section{1. 측정도구 및 방법}

1) 측정도구

본 연구에 사용된 마네킹은 P 사(Proa, Korea)의 27인치 가발을 사용 하였으며 커트 후 디지털 자(Bl-dm; Bluetec, Korea)를 이용하여 각 포 인트 지점의 길이를 측정하였다. 또한 커트 시 각도계(제도삼각자세트, Starbox, Korea)를 사용하여 슬라이스의 중간 접점에서 각도를 측정하

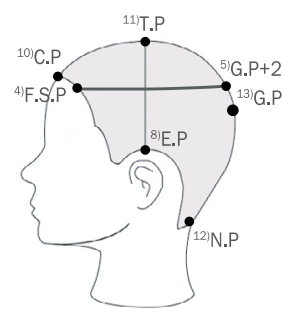

1) $\mathrm{F}-\mathrm{G}+2$

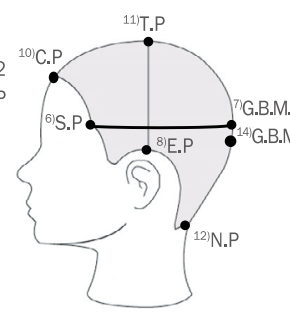

2) $\mathrm{S}-\mathrm{GBMP}+1$

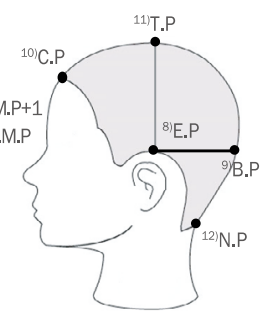

3) $E-B$

\section{Figure 1. Segmentation of head regions.}

${ }^{1)} \mathrm{F}-\mathrm{G}+2$, front side point - golden point $+2 \mathrm{~cm}$; ${ }^{2} \mathrm{~S}-\mathrm{GBMP}+1$, side point - golden back medium point $+1 \mathrm{~cm} ;{ }^{3} \mathrm{E}-\mathrm{B}$, ear point - back point ; ${ }^{4}$ F.S.P, front side point; ${ }^{5} \mathrm{G} . P+2$, golden point+2cm; ${ }^{6}$ S.P, side point; ${ }^{7)}$ G.B.M.P+1, golden back medium point+1cm; ${ }^{8}$ E.P, ear point; ${ }^{9}$ B.P, back point; ${ }^{10)}$ C.P, center point; ${ }^{11)}$ T.P, top point ; ${ }^{12)}$ N.P, nape point (Jang \& Jung, 2020); ${ }^{13)}$ G.P, golden point; ${ }^{14)}$ G.B.M.P, golden back medium point.

여 헤어 커트 하였다. 커트 시 커트 빗과 가위, 분무기, 클립이 사용되었 으며 시술 후 마무리를 위해 헤어 드라이기와 지름 $5 \mathrm{~cm}$ 폭의 롤 빗을 이용하여 모발의 결을 정리하였다. $1 \mathrm{~m}$ 의 일정한 간격을 둔 위치에서 디지털카메라(E-PL1; Olympus, China)를 사용하여 마네킹의 앞, 뒤, 옆 모습을 촬영하여 기록하였다.

\section{2) 측정 방법}

\section{(1) 두상의 영역분할}

두상의 지점 중 center point (C.P)와 nape point (N.P)를 연결하고 top point (T.P)에서 ear point (E.P)를 연결하여 4등분 블로킹을 하였다 (Figure 1). 또한 모든 분할은 분할을 기준으로 상-하로 영역을 나누었 으며, 상•하로 영역을 분할하는 것은 두 개의 다른 커트 형태의 조합을 통해 다양한 헤어 디자인을 연출하기 쉽기 때문이다(Kim \& Lee, 2017).

첫번째 가로 분할은 양쪽 front side point (F.S.P)와 golden point (G.P)에서 $2 \mathrm{~cm}$ 위 지점을 연결하여 분할하였으며 $\mathrm{F}-\mathrm{G}+2$ 로 명명하였 다. 이 부분은 두상에서 가장 높은 지점인 T.P지점을 중심으로 하고 있 으며 볼륨을 표현하기에 효율적인 영역이다(Kim \& Lee, 2017).

두번째 가로 분할은 양쪽 side point (S.P)를 기점으로 golden back medium point (G.B.M.P)에서 $1 \mathrm{~cm}$ 위 지점을 연결하여 분할하였으며, $\mathrm{S}-\mathrm{GBMP}+1$ 로 명명하였다. 이 영역은 G.P지점을 중심으로 하고 있으 며 질감, 양감, 율동과 같은 커트 디자인을 형성하는 영역이다(Kim \& Lee, 2017).

세번째 가로 분할은 양쪽 ear point (E.P)와 back point (B.P)를 연결 하여 분할하였으며, 분할을 기준으로 상·하로 영역을 나누고 $\mathrm{E}-\mathrm{B}$ 로 명 명하였다. E-B의 영역은 커트의 형태선에 영향을 주는 영역이다(Hong \& Joo, 2015). 
마네킹의 두상을 $\mathrm{F}-\mathrm{G}+2, \mathrm{~S}-\mathrm{GBMP}+1, \mathrm{E}-\mathrm{B}$ 의 세가지 방법으로 분 할을 하고, 상단은 over zone, 하단은 under zone으로 명명하였다(Jang \& Jung, 2020b).

분할을 기준으로 아래에는 미디엄 그래주에이션 커트를 위에는 원랭 스 커트를 적용 한 후 $\mathrm{A}$ 라인, 평행, $\mathrm{V}$ 라인의 슬라이스 라인을 각각 적 용하여 커트하였다.

\section{(2) 모발 길이}

모든 작품에 사용된 길이 가이드는 nape point (N.P)에서 가로 세로 1 $\mathrm{cm}$ 를 취한 후 자연 시술각 $0^{\circ}$ 를 적용하여 $5 \mathrm{~cm}$ 의 길이로 커트하였으며 이는 커트의 형태 변화를 확인하기 위한 가장 이상적인 길이로 선행연 구를 바탕으로 선정하였다(Jung, 2011).

(3) 슬라이스 라인

슬라이스 라인은 $2 \mathrm{~cm}$ 폭으로 모든 작품에 동일하게 적용되었다. 커 트는 아래에서 위로 진행하였으며 후두부에서 측두부의 순서로 진행되 었다. 단 $\mathrm{V}$ 라인의 경우 분할의 상단부는 측두부에서 후두부로 커트가 진행되었다.

$\mathrm{A}$ 라인은 back nape medium point에서 $2 \mathrm{~cm}$ 아래 지점과 nape side point 지점을 연결하여 커트를 진행하였다.

평행 라인은 두상의 nape point 에서 $2 \mathrm{~cm}$ 위 지점을 평행으로 나누 고 이 슬라이스 라인을 기준으로 진행하였다.

$\mathrm{V}$ 라인은 nape point 와 nape side point에서 $5 \mathrm{~cm}$ 위 지점을 연결 하여 커트한 후 슬라이스 라인의 폭을 일정하게 하기 위해 nape point 에서 nape side point 방향으로 $2 \mathrm{~cm}$ 지점과 nape side point에서 2.5 $\mathrm{cm}$ 위 지점을 연결하여 위 가이드에 맞추어 한번 더 커트 하였다. 이는 섹션의 폭이 오버디렉션에 의한 커트의 길이 변화를 유발할 수 있다는 Han \& Youn (2007)의 선행 연구를 참고 한 것이다.

\section{(4) 시술각도}

두상 분할의 하단부에는 $45^{\circ}$ 의 미디엄 그래주에이션 커트를 적용하 였으며, 상단부는 자연시술각 $0^{\circ}$ 의 원랭스 커트를 적용하여 모든 작품 에 동일하게 커트하였다.
2. 헤어 커트 시 두상의 분할과 슬라이스 라인에 따른 미디엄 그래 주에이션 커트와 원랭스 커트 혼합의 커트형태와 길이 변화

헤어 커트 시에 두상의 분할과 슬라이스 라인에 따라 변화되 는 커트형태와 길이 변화를 실증하기 위해 두상의 영역을 $\mathrm{F}-\mathrm{G}+2$, $\mathrm{S}-\mathrm{GBMP}+1, \mathrm{E}-\mathrm{B}$ 의 세가지 방법으로 분할하였다. 분할한 후에 하단에 는 미디엄 그래주에이션 커트를 상단에는 원랭스 커트를 적용하였다.

두상을 세가지 영역별로 나눈 후 $\mathrm{A}$ 라인, 평행 라인, $\mathrm{V}$ 라인의 슬라 이스 라인을 적용하여 헤어 커트 하였다. 모든 섹션은 $2 \mathrm{~cm}$ 폭으로 일 정하게 나누어 아래에서 위로 커트를 하였으며, 뒤쪽에서 앞쪽으로 커 트를 진행하였다. $\mathrm{V}$ 라인의 경우 하단은 뒤에서 앞쪽으로 진행하였으 나 상단은 앞쪽에서 뒤쪽 방향으로 커트를 진행하였다.

모든 작품은 $5 \mathrm{~cm}$ 의 가이드 길이로 동일하게 블런트 커트(blunt cut)하였으며, 슬라이스 라인에 대해서 직각으로 빗질한 후 시술각도 를 적용하여 커트하였다. 커트 시술 후 변화되는 길이를 측정하기 위 해 두상에서 지점을 선정하여 일정한 방법으로 길이를 측정하였으며, 이때 선택된 지점은 nape point (이하 N.P), back point (이하 B.P), golden back medium point (이하 G.B.M.P), golden point (이하 G.P), top point (이하T.P), center point (이하C.P), nape side point (이하 N.S.P), ear point (이하 E.P), side corner point (이하 S.C.P)이다.

커트 후에는 헤어 드라이기와 롤 빗을 사용하여 모발의 결을 정리 하고 작품의 앞, 옆, 뒷모습을 촬영하여 커트형태의 변화를 기록하 였으며, 모든 작품에는 전개표를 작성해 커트의 과정을 제시하였다 (Jung, 2016).

\section{Results and Discussion}

1. 헤어 커트 시 두상의 분할과 $A$ 라인에 따른 미디엄 그래주에이 션 커트와 원랭스 커트 혼합의 커트형태변화

1) 두상의 분할과 $A$ 라인에 따른 미디엄 그래주에이션 커트와 원랭 스 커트 혼합의 전개표

본 연구의 모든 작품에 커트형태에 맞는 전개표를 제시하였다. 전 개표는 미용사가 디자인하고자 하는 헤어스타일을 미리 설계하고 결

Table 1. A planar diagram of mixing medium-graduation cut and one-length hair cut according to the division of head and an A-line

\begin{tabular}{lcc}
\hline Shape & Under & Medium-graduation cut \\
\cline { 2 - 3 } & Over & One-length cut \\
Length & & N.P $5 \mathrm{~cm}$ \\
Direction & & Forward slope \\
Slice line & & A line \\
Base & & Not applicable \\
Angle & Under & Head angle about $45^{\circ}$ \\
\hline
\end{tabular}

N.P, nape point. 
과를 예측할 수 있는 자료가 된다(Jung, 2016).

커트의 형태는 두상을 상·하로 분할 한 다음 하단에는 두상 시술각 $45^{\circ}$ 의 미디엄 그래주에이션 커트를 적용하고 상단에는 자연 시술각 $0^{\circ}$ 의 원랭스 커트를 적용할 것을 나타낸다(Table 1). 헤어 커트의 가이드 길이 는 $5 \mathrm{~cm}$ 로 설정할 것이며 전경사의 경사선을 이용하여 커트 할 것임을 나타낸다(Table 1). 이 경사선은 A라인의 형태선을 만들 것이며 베이스 는 해당 사항이 없다(Table 1).

2) 두상의 분할과 $A$ 라인에 따른 미디엄 그래주에이션 커트와 원랭스 커트 혼합의 커트형태변화

두상의 영역을 상•하로 분할한 후 상단에는 원랭스 커트를 적용하고 하단에는 미디엄 그래주에이션 커트를 혼합 적용하여 $\mathrm{A}$ 라인으로 헤어 커트한 작품의 결과를 Table 2에 나타냈다.

Table 2 의 앞모습을 보면 모든 분할에서 전경사의 형태선이 전면에서 도 확인되며 하단부에 적용된 미디엄 그래주에이션 커트의 형태는 전면 에서는 나타나지 않았다.

옆모습의 경우 모든 분할에서 전경사의 형태선과 무게선을 확인할 수 있었다. 또한 $\mathrm{F}-\mathrm{G}+2$ 와 $\mathrm{S}-\mathrm{GBMP}+1$ 에서 햄 라인(hem line)이 커트의 형태선에 그대로 반영 되어 나타난 것을 볼 수 있는데 이것으로 햄 라인 의 형태가 미디엄 그래주에이션 커트에 영향을 미친다는 사실을 알 수 있다. 또한 두상의 분할에서 미디엄 그래주에이션 커트의 영역이 커질 수록 후두부에 시술각도에 의한 볼륨이 형성된 것을 볼 수 있다. 이는 $\mathrm{A}$ 라인을 이용한 미디엄 그래주에이션 커트가 두상에 볼륨과 입체감을 부 여 해준다는 Jang \& Jung (2019b)의 연구와 일치하는 결과이다. 또한 분할의 경계가 분명하고 상•하 영역의 커트선의 연결이 매끄럽지 않았 으며 분할을 중심으로 하단의 거친 질감과 상단의 매끄러운 질감이 극 명하게 나타났다. 커트 형태에서 느낄 수 있는 무거움과 가벼움이 커트 의 분할을 기준으로 나타났으며 하단에 적용된 미디엄 그래주에이션 커 트에서는 단차에 의한 안말음 효과가 나타났다.

Table 2 의 사진을 보면 뒷모습에서도 $\mathrm{A}$ 라인의 형태선과 무게선이 확 인된다. N.P와 N.S.P선상에서 볼 수 있는 A라인의 형태선은 미디엄 그 래주에이션 커트가 슬라이스 라인의 영향을 받는 다는 것을 증명한다. 분할의 경계가 분명하며 상단과 하단이 연결되지 않은 듯한 커트 의 형 태가 나타났다. 커트 형태의 특징에서 오는 거친 질감과 매끄러운 질감 이 후두부에서도 보여지며 원랭스 커트의 무거움과 미디엄 그래주에이 션 커트의 가벼움이 분할을 중심으로 극명하게 나타나는 것을 확인할 수 있다.

\section{2. 헤어 커트 시 두상의 분할과 평행 라인에 따른 미디엄 그래주에이 션 커트와 원랭스 커트 혼합의 커트형태변화}

1) 두상의 분할과 평행 라인에 따른 미디엄 그래주에이션 커트와 원랭 스 커트 혼합의 전개표

Table 3의 전개표는 길이 가이드는 N.P $5 \mathrm{~cm}$ 를 적용하여 커트 할 것 이며 상·하로 두상을 분할 한 뒤 상단에는 자연시술각 $0^{\circ}$ 의 원랭스 커트
를 하단에는 두상시술각 $45^{\circ}$ 의 미디엄 그래주에이션 커트를 적용할 것 을 설계한 것이다. 또한 커트의 방향과 슬라이스 라인은 모두 평행으로 하겠다는 것을 의미한다.

2) 두상의 분할과 평행 라인에 따른 미디엄 그래주에이션 커트와 원랭 스 커트 혼합의 커트형태변화

두상의 영역을 상•하로 분할한 후 상단에는 원랭스 커트를 적용하고 하단에는 미디엄 그래주에이션 커트를 혼합 적용하여 평행 라인으로 헤 어 커트한 작품의 결과를 Table 4에 나타냈다.

Table 4에서 앞모습을 살펴보면 상단에 적용된 원랭스 커트에 의한 평 행의 무게선이 확인되며, 하단에 적용된 미디엄 그래주에이션 커트가 전 면에서도 관찰 됐다. 또한 분할을 중심으로 커트 형태의 무거움과 가벼움 이 극명하게 나타났다. $\mathrm{F}-\mathrm{G}+2$ 를 보면 $\mathrm{E}-\mathrm{B}$ 에서 $\mathrm{F}-\mathrm{G}+2$ 로 갈수록 미디 엄 그래주에이션 커트의 영역 비중의 증가로 실루엣이 둥글게 나타난 것 을 확인할 수 있다.

옆모습을 살펴보면 평행의 형태선이 나타났으며 분할을 중심으로 평행의 무게선이 선명하게 나타난 것을 볼 수 있다. 또한 $\mathrm{E}-\mathrm{B}$ 에서 $\mathrm{F}-\mathrm{G}+2$ 로 갈수록 실루엣이 둥글어 졌으며 분할을 중심으로 거친 질감 과 매끄러운 질감이 대조적으로 나타났다. $\mathrm{F}-\mathrm{G}+2$ 에서 $\mathrm{E}-\mathrm{B}$ 로 갈수록 원랭스 커트의 무게감이 많이 느껴지며 반대로 $\mathrm{E}-\mathrm{B}$ 에서 $\mathrm{F}-\mathrm{G}+2$ 로 갈 수록 볼륨감과 입체감이 두드러지게 나타났다. 이것은 커트 종류의 혼 합 위치에 따라 다른 느낌의 커트 디자인 창출이 가능하다는 결과를 도 출한 $\operatorname{Kim}$ (2015)의 연구와 일치하는 결과이다

뒷모습 사진을 보면 $\mathrm{F}-\mathrm{G}+2$ 에서 $\mathrm{E}-\mathrm{B}$ 로 갈수록 분할의 경계가 더 분 명해지며 원랭스 커트의 무거움이 부각되는 것을 볼 수 있다. 또한 상단 과 하단의 커트 형태가 분리 된 듯 보이며 무거움과 가벼움, 매끄러움과 거친 질감이 분할을 중심으로 극명하게 나타난 것을 확인했다.

\section{3. 헤어 커트 시 두상의 분할과 $\mathrm{V}$ 라인에 따른 미디엄 그래주에이션 커트와 원랭스 커트 혼합의 커트형태변화}

1) 두상의 영역분할과 $\vee$ 라인에 따른 미디엄 그래주에이션 커트와 원랭스 커트 혼합의 전개표

Table 5 의 전개표는 $5 \mathrm{~cm}$ 의 길이가이드를 기준으로 커트할 것이며 분할을 중심으로 상단에는 자연 시술각 $0^{\circ}$ 의 원랭스 커트를 하단에는 두상 시술각 $45^{\circ}$ 의 미디엄 그래주에이션 커트를 적용할 것임을 계획한 것이다. 커트의 방향은 후경사를 적용할 것이며 V라인의 슬라이스 라 인을 사용하여 헤어 커트 할 것임을 나타낸다.

헤어 커트 전개표는 시술방법과 과정을 작성해 보며 헤어스타일을 구상해 보는 절차로 커트 교육 시 형성평가, 총괄평가 등의 기초 평가 자료로 사용될 수 있다(Jung, 2016).

2) 두상의 분할과 $\vee$ 라인에 따른 따른 미디엄 그래주에이션 커트와 원랭스 커트 혼합의 커트형태변화

두상의 영역을 상•하로 분할한 후 상단에는 원랭스 커트를 적용하고 
Table 2. Changes in hair cut shape by mixing medium-graduation cut and one-length hair cut according to the division of head and an A-line

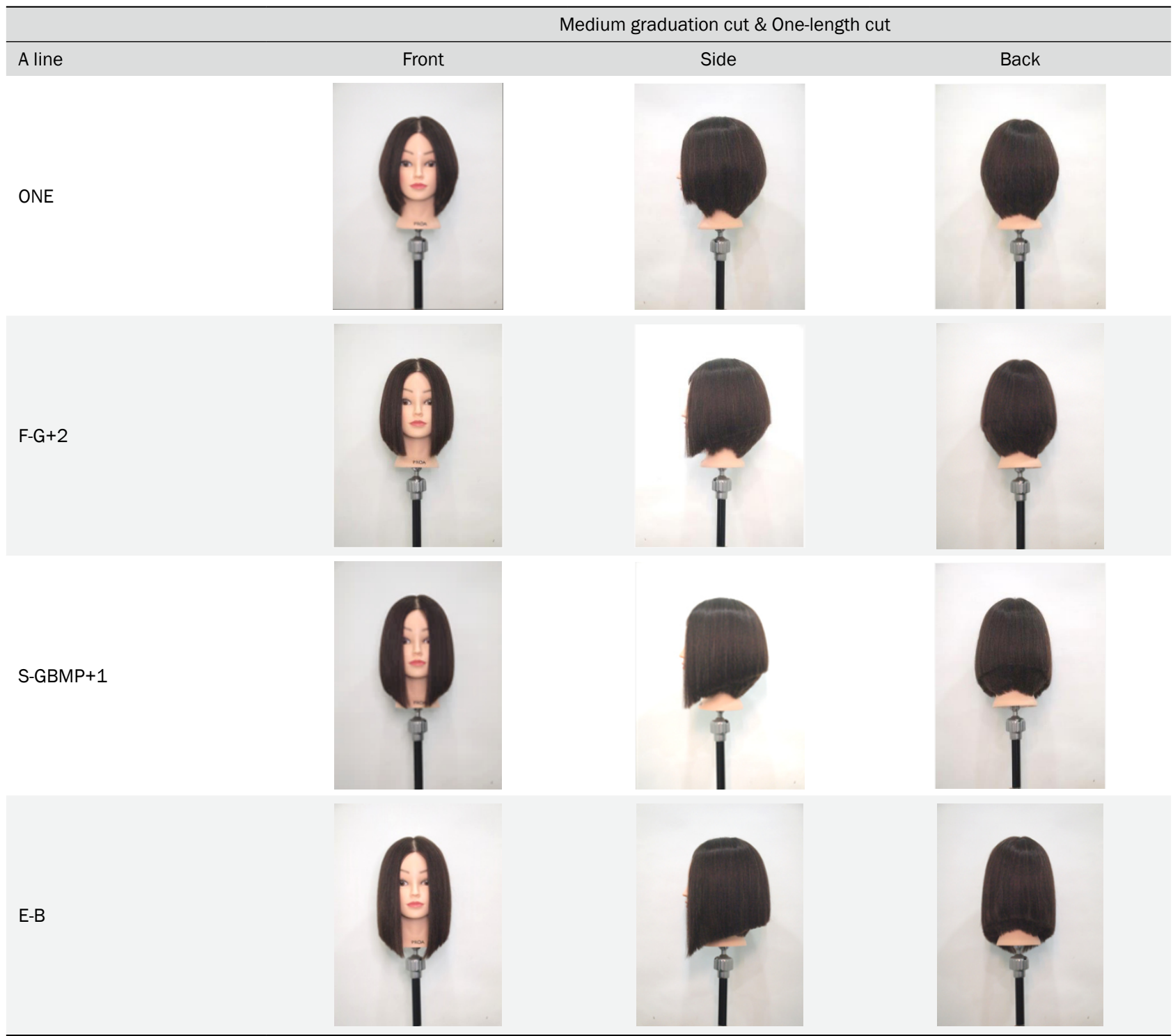

$\mathrm{F}-\mathrm{G}+2$, front side point-golden point+2; $\mathrm{S}-\mathrm{GBMP}+1$, side point-golden back medium point+1; $\mathrm{E}-\mathrm{B}$, ear point-back point; $\mathrm{A}$ line, concave line; $\mathrm{V}$ line, convex line.

Table 3. A planar diagram of mixing medium-graduation cut and one-length hair cut according to the division of head and a parallel

\begin{tabular}{lcc}
\hline \multirow{2}{*}{ Shape } & Under & Medium-graduation cut \\
\cline { 2 - 3 } \cline { 3 - 3 } Length & Over & One-length cut \\
Direction & & N.P $5 \mathrm{~cm}$ \\
Slice line & & Parallel \\
Base & & Parallel line \\
Angle & Under & Not applicable \\
& Over & Head angle about $45^{\circ}$ \\
\hline
\end{tabular}

N.P, nape point. 
Table 4. Changes in hair cut shape by mixing medium-graduation cut and one-length hair cut according to the division of head and a parallel

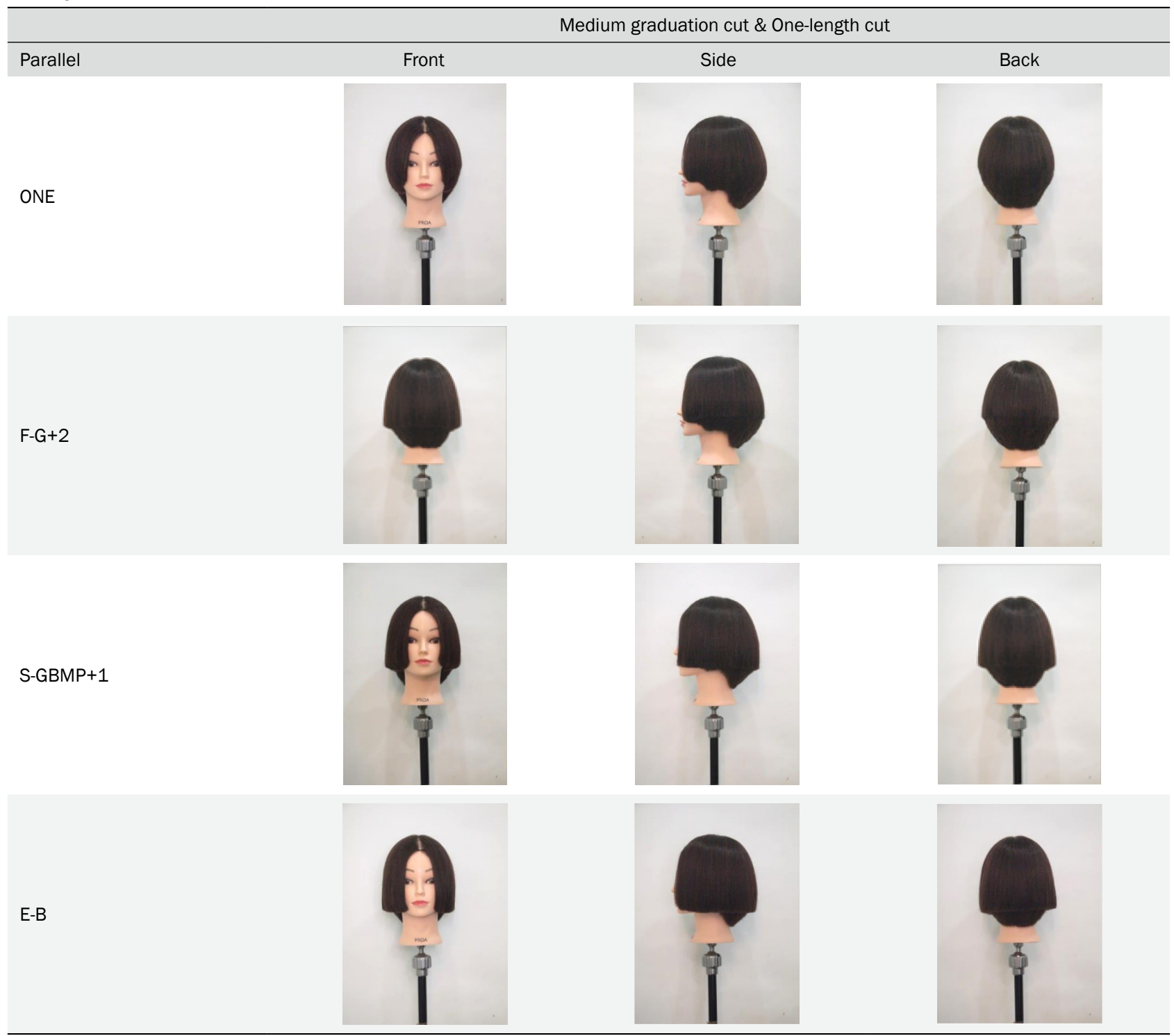

F-G+2, front side point-golden point+2; S-GBMP+1, side point-golden back medium point+1; E-B, ear point-back point; A line, concave Line; $\checkmark$ line, convex Line.

Table 5. A planar diagram of mixing medium-graduation cut and one-length hair cut according to the division of head and a V-line

\begin{tabular}{lcc}
\hline Shape & Under & Medium-graduation cut \\
\cline { 2 - 3 } & Over & One-length cut \\
Length & & N.P $5 \mathrm{~cm}$ \\
Direction & & Rear slope \\
Slice line & & V line \\
Base & & Not applicable \\
Angle & Under & Head angle about $45^{\circ}$ \\
\hline
\end{tabular}

N.P, nape point. 
하단에는 미디엄 그래주에이션 커트를 혼합 적용하여 $\mathrm{V}$ 라인으로 헤어 커트한 작품의 결과를 Table 6에 나타냈다.

Table 6의 앞모습을 보면 후경사의 형태선이 전면에서도 확인 할 수 있었으며, 하단에 적용된 미디엄 그래주에이션 커트의 거친 질감과 가 벼움은 전면에서 보이긴 하나 상단에 적용된 원랭스 커트의 무겁고 매 끄러운 질감에 의해 부각되지 않는다. $\mathrm{F}-\mathrm{G}+2$ 를 보면 하단의 미디엄 그래주에이션 커트의 영역 비율이 높아 짐에 따라 실루엣이 둥글어지며 커트 형태에 영향을 미치는 것으로 확인되었다.

옆모습을 살펴보면 후경사의 형태선과 무게선이 관찰되며 하단의 적 용된 미디엄 그래주에이션 커트는 햄 라인에 영향을 받는 것으로 확인 된다. 거친 질감과 매끄러운 질감이 분할을 중심으로 대조적으로 나타
났으며 후경사의 경사도는 시각적으로 후두부에 무게감을 가중시킨다. 상단과 하단의 커트선의 연결이 부자연스러우며 상단과 하단에 독립된 커트의 형태가 나타났다. 이는 상단에 적용된 원랭스 커트의 가이드가 정중선이 아닌 측면에 있는 이유로 상-하의 커트 선이 서로 연결 되지 않은 디스커넥션 커트(disconnection cut)가 나타난 것으로 사료된다

뒷모습의 경우 뚜렷한 후경사의 형태선과 무게선이 관찰되었다. 상 단에 적용된 원랭스와 후경사의 경사도로 인해 후두부에 무게감이 가중 되어 보인다. 상•하 연결되지 않은 커트 선이 후두부에서도 관찰된다. $\mathrm{F}-\mathrm{G}+2$ 와 $\mathrm{S}-\mathrm{GBMP}+1$ 에서 거친 질감과 매끄러운 질감이 대조적으로 나타났으며 $\mathrm{E}-\mathrm{B}$ 에서는 상단에 적용된 원랭스 커트로 인해 미디엄 그 래주에이션 커트의 모습은 잘 확인 되지 않는다.

Table 6. Changes in hair cut shape by mixing medium-graduation cut and one-length hair cut according to the division of head and a V-line

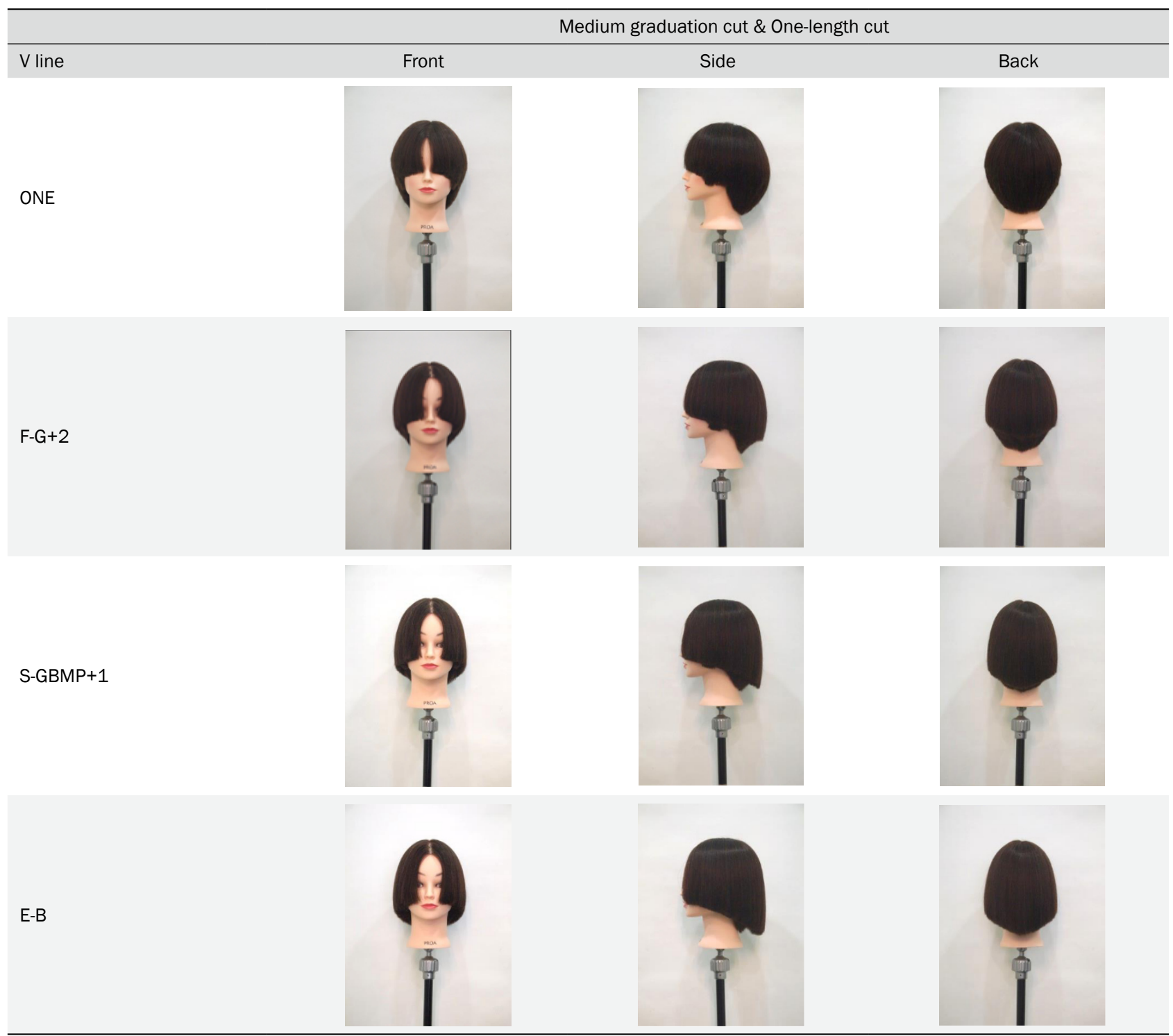

$\mathrm{F}-\mathrm{G}+2$, front side point-golden point+2; $\mathrm{S}-\mathrm{GBMP}+1$, side point-golden back medium point+1; E-B, ear point-back point; A line, concave line; $\mathrm{V}$ line, convex line. 


\section{4. 헤어 커트 시 두상의 분할과 슬라이스 라인에 따른 미디엄 그래 주에이션 커트와 원랭스 커트 혼합의 길이변화}

Table 7은 두상의 영역을 세가지 형태로 분할한 후 상단에는 원랭 스 커트를 하단에는 미디엄 그래주에이션 커트를 적용하고 다양한 슬라이스 라인을 이용해 헤어 커트한 작품의 길이 변화를 나타내었 다.

Table 7을 보면 A라인과 평행 라인에서 B.P에서 G.P까지의 길이 가 동일하게 측정된 것을 볼 수 있는데 이는 C.P에서 N.P까지 연결 되는 정중선이 커트의 가이드가 되기 때문이다.

$\mathrm{A}$ 라인에서 보면 T.P와 C.P의 길이가 일치하는 것으로 측정되었 다. 이는 슬라이스 라인의 경사도로 인해 T.P와 C.P가 한 패널로 연 결 되어 있다는 것을 나타낸다. 이는 Jang \& Jung (2020a)의 연구 결과와 일치하는 결과로 슬라이스 라인에 대해 직각으로 빗질을 하 였다는 것을 증명한다.

슬라이스 라인에 따라 N.S.P의 길이와 S.C.P의 길이가 변화되는 것은 미디엄 그래주에이션 커트에서 슬라이스 라인의 변화는 형태 선에 그대로 반영되어 나타난 다는 것을 증명해 주는 결과이다.

$\mathrm{V}$ 라인에서 $\mathrm{F}-\mathrm{G}+2, \mathrm{~S}-\mathrm{GBMP}+1, \mathrm{E}-\mathrm{B}$ 모두 분할을 중심으로 상•하의 길이 차이의 변화가 크게 측정되었다. 이는 가이드가 중심 에서 시작된 커트가 상단에 와서 측면으로 바뀌며 상·하 연결되지 않은 디스커넥션 커트(disconnection cut)가 되었음을 뜻한다(Jang \& Jung, 2020b).

\section{Conclusion}

헤어 커트는 헤어 미용의 영역 중에서도 구조적인 틀을 만드는 작
업으로 헤어 디자인에서 그 비중이 크나 체계화와 수치화 된 선행연 구가 부족하여 그 필요성이 요구되는 실정이다. 헤어 커트 방법의 체계화와 수치화는 전문성을 바탕으로 쉽고 빠른 커트디자인을 가 능하게 해 줄 것이다.

이에 본 연구는 기초 헤어 커트에 해당하는 미디엄 그래주에이션 커트와 원랭스 커트를 두상의 영역분할에 따라 혼합한 후 슬라이스 라인에 따라 변화되는 커트의 형태변화와 길이변화를 실증하여 헤 어 커트 교육의 기초자료로 제공하고자 연구하였으며 그 결과는 다 음과 같다.

첫째, 미디엄 그래주에이션 커트가 분할의 하단에 적용되었을 때 헤어 라인의 모양이 형태선에 그대로 반영되어 나타난 것을 볼 수 있다. 이는 헤어 디자이너가 헤어 커트를 진행할 때 층이 생기는 커 트형태에서는 헤어 라인의 형태를 유념해서 커트 해야 한다는 것을 증명 하는 것으로 사료된다.

둘째, 두상의 영역을 분할하고 미디엄 그래주에이션 커트와 원랭 스 커트를 혼합 적용한 결과 커트가 혼합된 위치에 따라 커트의 형 태가 변화되었다. 이것으로 분할의 위치를 이용하여 커트의 형태를 자유롭게 조절할 수 있으며, 고객의 요구와 디자이너의 감성 또한 만족 시킬 수 있을 것으로 사료된다

셋째, 같은 영역의 분할과 커트 형태의 혼합에서 슬라이스 라인의 변화 만으로 전면에서 보여지는 커트 형태가 바뀌는 것을 확인할 수 있었으며, 이는 슬라이스 라인을 이용하여 얼굴형의 단점을 보완하 며 커트형태의 변화를 유도할 수 있을 것으로 사료된다.

이로써 미디엄 그래주에이션 커트와 원랭스 커트를 두상의 영역 분할에 혼합한 후 슬라이스 라인에 따라 변화되는 커트의 형태변화 와 길이 변화를 실증하여 헤어 커트 교육의 기초자료로 제공하였다.

이러한 연구를 바탕으로 헤어 커트의 체계화, 수치화에 대한 연구

Table 7. Hair length changes by mixing medium-graduation cut and one-length hair cut according to the division of head

\begin{tabular}{lllllllllll}
\hline Shape & & N.P & N.S.P & E.P & S.C.P & B.P & G.B.M.P & G.P & T.P & C.P \\
\multirow{4}{*}{ A line } & ONE & 5.0 & 7.5 & 13.0 & 12.5 & 9.5 & 11.5 & 13.5 & 18.5 & 18.5 \\
& F-G+2 & 5.0 & 7.5 & 13.0 & 12.5 & 9.5 & 11.5 & 13.0 & 22.5 & 22.0 \\
& S-GBMP+1 & 5.0 & 7.5 & 13.0 & 12.5 & 9.5 & 11.5 & 15.5 & 24.0 & 24.0 \\
& E-B & 5.0 & 7.5 & 15.0 & 15.0 & 9.5 & 13.5 & 17.5 & 28.0 & 28.0 \\
& ONE & 5.0 & 5.0 & 9.5 & 7.5 & 9.5 & 11.5 & 13.5 & 17.5 & 12.5 \\
\multirow{5}{*}{ Parallel } & F-G+2 & 5.0 & 5.0 & 9.5 & 7.5 & 9.5 & 11.5 & 13.5 & 20.0 & 12.5 \\
& S-GBMP+1 & 5.0 & 5.0 & 10.0 & 7.5 & 9.5 & 11.5 & 15.5 & 21.5 & 12.5 \\
& E-B & 5.0 & 5.0 & 10.0 & 7.5 & 9.5 & 13.5 & 17.5 & 23.0 & 15.0 \\
& ONE & 5.0 & 4.5 & 7.5 & 4.5 & 9.5 & 11.5 & 13.5 & 21.0 & 9.5 \\
& F-G+2 line & 5.0 & 4.5 & 7.5 & 4.5 & 9.5 & 15.5 & 21.0 & 21.0 & 11.0 \\
& S-GBMP+1 & 5.0 & 4.5 & 7.5 & 4.5 & 9.5 & 17.0 & 22.0 & 22.0 & 12.0 \\
& E-B & 5.0 & 4.5 & 7.5 & 5.5 & 13.0 & 17.0 & 22.0 & 22.0 & 13.0 \\
\hline
\end{tabular}

N.P, nape point; N.S.P, nape side point; E.P. ear point; S.C.P, side corner point; B.P., back point; G.B.M.P, golden back medium point; G.P, golden point; T.P, top point; C.P, center point; $F-G+2$, front side point-golden point+2; S-GBMP+1, side point-golden back medium point+1; E-B, ear point-back point; $A$ line, concave line; $\mathrm{V}$ line, convex line. 
가 지속될 수 있기를 바라는 바이며 향후 연구에서는 다양한 영역의 분할과 슬라이스 라인에 따라 달라지는 커트 스타일을 비롯하여 커 트 요소들의 조합을 통한 창의적인 헤어 디자인에 관한 연구가 지속 적으로 이루어져야 할 것이다.

\section{Author's contribution}

SMJ designed, performed experiments, and wrote the manuscript. JWJ has contributed greatly to the review and writing of the manuscript.

\section{Author details}

Seon-Mi Jang (Graduate student), Department of Beauty Science, Kwangju Women's University, 69 Gwangju Yeodae Gil, Gwangsangu, Gwangju Gwang-Yeogsi 62396, Korea; Won-Ji Jung (Professor), Department of Beauty Science, Kwangju Women's University, 69 Gwangju Yeodae-gil, Gwangsan-gu, Gwangju 62396, Korea.

\section{References}

Han JS, Youn CS. A study on analysis of hair cut line based on the pythagorean theorem: focused on overdirection. Journal of Beauty Industry, 2: 53-74, 2007.

Hong SH, Joo YB. 7-Section\&Zone for scalp division used in cutting hair. Journal of the Korean Society of Beauty and Art, 16: 203-211, 2015.

Jang SM, Jung WJ. Shape changes duo to the slope of the forward slope slice line in graduation haircuts. Asian Journal of Beauty and Cosmetology, 17: 211-221, 2019a.

Jang SM, Jung WJ. Shape change according to the mixing of forward and rear slope slice lines in graduation haircuts. Asian Journal of Beauty and Cosmetology, 17: 375-385, 2019b.

Jang SM, Jung WJ. Changes in shape of the combination of a one-length cut and a medium-graduation cut according to segmentation of head regions and slice lines. Asian Journal of Beauty and Cosmetology, 18: 221-233, 2020a.

Jang SM, Jung WJ. Changes in haircut shape by mixing a onelength haircut and same layer haircut according to the division of head and slice lines during hair cutting. Asian Journal of Beauty and Cosmetology, 18: 559-570, 2020b.

Jung WJ. An empirical study of the graduation cut on the basic haircut. Journal of Beauty Industry, 10: 47-62, 2016.
Jung WJ, Youn CS. Factors of form change by hair-cut. Journal of the Korean Society of Cosmetology, 14: 893-899, 2008.

Jung WJ. Form change of hair style in relation with hair length, base, and angle in A-line hair-cut. Journal of Investigative Cosmetology, 7: 197-205, 2011.

Jung WJ, Kim Cl. An empirical study on the mixed style of isadora bob cut and graduation cut. Journal of Beauty Industry, 11: 37-53, 2017.

Kim SH. A study on form changes of hair styles after adjustment in hair cut section line and combination position: focusing on graduation haircut and increase layer haircut. Journal of the Korean Society of Cosmetology, 21: 1173-1181, 2015.

Kim SH. A study on hair style changes by changes in the volume of hair cut blocks, hair length and section line in hair cut: focusing on one length cut and increase layered cut. Journal of the Korean Society of Cosmetology, 22: 13411351, 2016.

Kim JS, Kang JA, Goh SH, Gwak HS, Kwon EJ, Kim MJ, Kim SW, Kim OG, Kim TY, Kim HT, et al. Basic haircut. Korea Research Institute for Vocational Education \& Training, Sejong, pp64-109, 2018.

Kim HM, Lee JS. A study on the male hair cut section division. Journal of the Korean Society of Cosmetology, 23: 811823, 2017.

Kang PM. An analysis of hair renderings in reference to entertainers' hair styles: focused on Byeon Jeong-su's hair styles. Journal of the Korean Fashion \& Beauty, 1: 105118, 2003.

Kwon $\mathrm{OH}$, Park EJ, Chung SM, Kim KY. Investigation into perception and necessity of hair length's standard point in hair cut education. Journal of Investigation Cosmetology, 6: 131-139, 2010.

Lee $\mathrm{OH}$, Jin YM. A study of one-length cut by the Korean's face types. Journal of Beauty Art Management, 4: 81-90, 2010.

Lee MS. A study on vidal sassoon hair cutting. Journal of the Korean Society of Cosmetology, 6: 675-687, 2000.

Lee S, Park HS. NCS course design and result analysis of class application. Journal of The Korea Society of Computer and Information, 9: 157-163, 2016.

Seo SA, Song YS. A study on satisfaction according to techniques creation and application of hair cut using hair stream. Journal of the Korean Society of Beauty Cultural Arts, 8: 18-36, 2019. 


\section{국문초록}

\section{헤어 커트 시 두상의 분할과 슬라이스 라인에 따른 미디엄 그래주에이션 커트와 원랭 스 커트 혼합의 커트형태변화 |}

장선미, 정원지

광주여자대학교 미용과학과, 광주, 한국

목적: 기초 헤어 커트에 해당하는 미디엄 그래주에이션 커트와 원랭스 커트를 두상의 영역분할에 혼합 적용한 후 슬라이스 라인 에 따라 변화되는 커트의 형태변화와 길이변화를 실증하여 헤어 커트 교육의 기초자료로 제공하고자 한다. 방법: 두상을 front side point-golden point+2 ( $\mathrm{F}-\mathrm{G}+2)$, side point-golden back medium point+1 (S-GBMP+1), ear point-back point (E-B)로 분할한 후 상단에는 원랭스 커트를 하단에는 미디엄 그래주에이션 커트를 혼합 적용한 후 $\mathrm{A}$ 라인, 평행, $\mathrm{V}$ 라인의 슬라이스 라인을 적용하 여 헤어 커트 하였다. 결과: 두상을 분할한 후 상단에는 원랭스 커트를 하단에는 미디엄 그래주에이션 커트를 적용한 결과 분할의 위치에 따라 커트 형태와 길이 변화가 나타났으며, 형태선은 미디엄 그래주에이션 커트의 슬라이스 라인에 영향을 받는 것으로 확 인됐다. 결론: 기초 커트의 조합은 분할의 위치에 따라 적용된 커트의 특성이 커트 형태에 영향을 주며 다양한 슬라이스 라인을 적 용했을 때 개성 있고 창의적인 커트 디자인을 가능하게 한다는 것을 실증하였다.

핵심어: 기초 커트, 슬라이스 라인, 원랭스 커트, 혼합 커트, 미디엄 그래주에이션 커트

\section{참고문헌}

강평미. 연예인 헤어스타일에 근거한 헤어연출 분석: 변정수 헤어스타일을 중심으로. 한국패션뷰티학회지, 1: 105-118, 2003.

김순희. 헤어 커트의 섹션라인과 혼합위치의 변화에 따른 헤어스타일의 형태변화에 관한 연구: 그래쥬에이션 커트와 인크 리스 레이어 커트 혼합을 중심으로. 한국미용학회지, 21: 1173-1181, 2015.

김순희. 헤어 커트에 있어서 커트 블럭의 량과 모발의 길이, 섹션 라인의 변화에 따른 헤어스타일의 형태 변화에 관한 연 구: 원랭스 커트와 인크리스 레이어 커트를 중심으로. 한국미용학회지, 22: 1341-1351, 2016.

김진숙, 강주아, 고성현, 곽형심, 권은경, 김민정, 김서원, 김옥기, 김태영, 김현태 et al. 기초 헤어 커트. 한국직업능력개

발원, 세종시, pp64-109, 2018a.

김상진, 김인엽, 이지현. 기초헤어 커트. 한국직업능력개발원, 세종시, pp47-48, $2018 \mathrm{~b}$.

김혜민, 이재숙. 남성 헤어 커트 섹션 분할 연구. 한국미용학회지, 23: 811-823, 2017.

권오혁, 박은준, 정성모, 김기영. 커트교육 시 모발길이의 기준점에 대한 인식과 필요성에 관한 조사. 대한미용과학회지,

6: 131-139, 2010.

서순애, 송연숙. 모류(毛流)를 이용한 헤어 커트 기법 개발과 적용에 따른 만족도 연구. 대한미용문화예술학술지, 8: 18-

36, 2019.

이명실. 비달사순 헤어커팅 연구: Consultation 과 Round Graduation 에 대해. 한국미용학회지, 6: 675-687, 2000.

이옥현, 진용미. 한국인 얼굴형태에 따른 원랭스 커트 연출에 대한 연구. 미용예술경영연구, 4: 81-90, 2010.

이순미, 박혜숙. NCS 교과목 개발 및 수업 적용 결과 분석. 한국컴퓨터정보학회논문지, 9: 157-163, 2016.

장선미, 정원지. 그래주에이션 커트의 전경사 슬라이스 라인 기울기에 따른 형태변화. 아시안뷰티화장품학술지, 17: 211-

221, 2019a.

장선미, 정원지. 그래주에이션 커트에 전경사와 후경사 슬라이스 라인의 혼합에 따른 형태변화. 아시안뷰티화장품학술지, 
17: 375-385, 2019b.

장선미, 정원지. 두상의 영역분할과 슬라이스 라인에 따른 원랭스 커트와 미듐 그래주에이션 커트 혼합의 형태변화. 아시 안뷰티화장품학술지, 18: 221-233, 2020a.

장선미, 정원지. 헤어커트 시 두상의 분할과 슬라이스 라인에 따른 원랭스 커트와 세임 레이어 커트 혼합의 커트형태변화. 아시안뷰티화장품학술지, 18: 559-570, 2020b.

정원지. 윤천성. 헤어 커트의 形態에 變化를 주는 要因에 관한 연구. 한국미용학회지, 14: 893-899, 2008.

정원지. 기본헤어 커트에서 그래쥬에이션 커트의 실증연구. 뷰티산업연구, 10:47-62, 2016.

정원지. 헤어 커트 시 A라인에서 모발길이와 베이스와 각도에 따른 헤어스타일의 형태변화. 대한미용학회지, 7: 197205, 2011.

정원지, 김춘일. 이사도라 보브형 커트와 그래쥬에이션 커트의 혼합형스타일에 대한 실증연구. 뷰티산업연구, 11: $37-53$, 2017.

한지승, 윤천성. 피타고라스의 정리를 이용한 헤어컷 라인분석: 오버다이렉션(Overdirection)을 중심으로. 뷰티산업연구, 2: 53-74, 2007.

홍성희, 주연빈. 헤어 커트에 사용되는 두상 분할에 대한 7섹션 존 연구. 한국인체미용예술학회지, 16: 203-211, 2015. 


\section{中文摘要}

\section{剪发过程中根据头线和切片线的划分，通过混合中等长度的发型和一种长度的 发型来改变发型形态 I}

張先美, 鄭圓至

光州女子大学美容科学科, 光州, 韩国

目的：通过结合头皮的划分，使用中等梯度剪线和单头剪两种基本发型，根据切片线的位置改变发型的形态和 长度的变化, 为发型教学提供基础数据。方法: 将头发分为正面点-黄金点+2（F-G+2），侧面点-黄金背中点 $+1(S-G B M P+1)$ 和耳朵点-背点 (EB) 分别在上部和下部分别进行了定尺切割和中等刻度切割。最后, 使用 $A$ 线, 平行线和 $V$ 线的切片线完成剪发。结果: 将头发划分后, 将一头剪裁到上部, 将中等刻度剪裁到下部。结 果，发型的形状和头发的长度根据分割的位置而变化，并且发现形状线受到中等刻度的切口的切片线的影响。 结论: 当将基本发型组合在一起时, 发型的形状会根据应用于每个分割位置的发型的特性而变化, 并且在应用不 同的切片线时可以设计出独特而富有创意的发型。

关键词: 理发, 裁线, 中度毕业剪, 单头剪, 组合剪 